\title{
Effects of Three Production Systems on Muskmelon Yield and Quality in New England
}

\author{
Mina Vescera and Rebecca Nelson Brown ${ }^{1,2}$ \\ Department of Plant Sciences and Entomology, University of Rhode Island, \\ Kingston, RI 02881
}

Additional index words. Cucumis melo, high tunnels, low tunnels, plasticulture, growing degree-days

\begin{abstract}
Muskmelons (Cucumis melo L.) are routinely grown on black plastic mulch, as the associated increase in soil temperatures, more stable soil moisture, and decreased weed competition result in higher yields than in bare soil production. However, mulch does little to moderate air temperature, which can be below optimum for melon production under New England conditions. One option for increasing air temperature is to grow plants in unheated hoophouses, or high tunnels. Another option is to use low tunnels consisting of ventilated clear plastic rowcovers supported over wire hoops. This study compared low tunnels and high tunnels to open field production for muskmelon production in a peri-urban market farm system in Rhode Island. Five hybrid muskmelon cultivars were grown for 2 years to compare earliness, yield, and fruit quality among the three production systems. Both tunnel systems increased the rate at which growing degree-days (GDD) accumulated relative to open field production, and resulted in statistically significant differences in starting date of first harvest, with fruit in the high tunnel treatment ripening first. The high tunnel production system increased yields per hectare in both years relative to the other production systems due to increased planting density, but not due to increased yields per plant. Marketable yields per hectare from the high tunnel system significantly exceeded those from the open field for four out of the five cultivars in 2011, but for only one out of five cultivars in 2012. Marketable yields from the low tunnel system were $\approx \mathbf{1 0} \%$ higher than the open field in $\mathbf{2 0 1 1}$, and almost double the open field yields in 2012. Fruit from the low tunnels had the highest concentration of soluble solids in both years. The high tunnel production system did not increase yields sufficiently to offset the associated increase in costs of production, suggesting that muskmelon is not a good crop for high tunnel production in New England. In contrast, a yield increase of only $15 \%$ would be sufficient to offset the increased costs of employing the low tunnel production system. Low tunnels have the potential to greatly benefit muskmelon production in New England, particularly in years or locations where GDD accumulate slowly.
\end{abstract}

The vegetable industry in New England (and other peri-urban areas) is dominated by small-scale producers who market directly to consumers (USDA, 2012, 2013). Farmers grow a diverse mix of crops and rely on season extension technologies, such as high tunnels, rowcovers, and greenhouse-grown transplants, to meet customer demand for fresh local produce throughout the year (Sassenrath et al., 2010). Plasticulture, including rowcovers and high tunnels as well as plastic mulch, has been an important tool for crop diversification and season extension as it enables farmers in New England to create

Received for publication 24 Nov. 2015. Accepted for publication 3 Mar. 2016.

This research was funded by project H-673-INT of the Rhode Island Agricultural Experiment Station. This paper is a portion of the Masters of Science thesis of the first author, currently an extension educator at Cornell Cooperative Extension of Suffolk County, Riverhead, NY 11901.

${ }^{1}$ Associate Professor.

${ }^{2}$ Corresponding author. E-mail: brownreb@uri.edu.
20 to $23{ }^{\circ} \mathrm{C}$ during the production season. Muskmelons are typically grown on raised beds covered with black plastic mulch, which has been shown to increase earliness by up to $7 \mathrm{~d}$ and to double yields over planting in bare soil (Loy and Wells, 1975). However, mulch does little to enhance air temperature (Loy and Wells, 1975). High tunnels are increasingly common on market farms in New England but are mostly used for tomato production; there have been no studies evaluating high tunnels for melon production under New England conditions. Low tunnel melon production systems were investigated in New Hampshire many years ago using open-pollinated varieties (Loy and Wells, 1975), but the recent hybrids developed for New England conditions have not been tested in tunnels (Loy, 2013). The objective of this study was to compare performance of low tunnel, high tunnel, and open field production systems across multiple muskmelon cultivars under southern New England conditions. Production under each system was evaluated for earliness, yield, and fruit quality.

\section{Materials and Methods}

Research was conducted during the summer growing seasons (May through August) of 2011 and 2012 at the University of Rhode Island Greene H. Gardiner Agricultural Experiment Station (Kingston, RI). Kingston is located at $41^{\circ} \mathrm{N}$ latitude and is $\approx 8 \mathrm{~km}$ inland from the Atlantic Ocean. Annual precipitation averages $134 \mathrm{~cm}$ with $\approx 10 \mathrm{~cm}$ per month during the growing season. The soil is Bridgehampton and Enfield silt loams, with a $\mathrm{pH}$ of 6.5 after liming and an electrical conductivity below $0.2 \mathrm{mS} \cdot \mathrm{cm}^{-1}$.

Cultivars. Five hybrid muskmelon cultivars (Athena, Lil' Loupe, Sarah's Choice, Tasty Bites, and Sivan) were selected for inclusion in the trial based on their days to maturity, suitable fruit size, and resistance to powdery mildew. 'Sarah's Choice' (Johnny's Selected Seeds, Winslow, ME) was developed specifically for field production in New England by Brent Loy at the University of New Hampshire. Athena (Syngenta, Greensboro, $\mathrm{NC}$ ) is a standard cultivar for field production in the eastern United States. Lil' Loupe (Abbott and Cobb, Feasterville, PA) and Tasty Bites (DP Seeds, Yuma, AZ) are single-serving cultivars. Sivan (Genesis Seeds, Rehovot, Israel) is a small-fruited charentais cultivar. Smallfruited cultivars were preferred as all melon types normally grown in New England slip from the stems when ripe, and larger fruit must be supported in trellised systems.

Transplant production. The melon plants were started in the greenhouse using Metromix 510 peat-based media (Sungro Horticulture, Agawam, MA) in 38-cell plug trays (5.7-cm-diameter cells) with one plant per cell. The greenhouse was maintained at $30^{\circ} \mathrm{C}$ day $/ 13{ }^{\circ} \mathrm{C}$ night without supplemental lighting. Seedlings were fertilized twice with a $1.5 \%$ solution of fish emulsion in water (3N-1.3P-0.2K; Organic Gem, New Bedford, MA). The intention was to transplant 
into the high tunnel around 15 May, which is the average last frost date at the farm, with the low tunnel and open field treatments transplanted 10 and $20 \mathrm{~d}$ later, respectively. Seeding dates were chosen to provide 3-week-old seedlings for transplanting (Howell and Hazzard, 2010). However, construction delays prohibited transplanting into the high tunnels until 31 May 2011. The initial set of plants for the high tunnels was replaced with plants seeded 26 Apr. to accommodate the delay. Dates of seeding and transplanting are shown in Table 1.

Cultural practices. Planting beds were covered with 0.025 -mm-thick embossed black plastic mulch (PolyExpert, Laval, QC, Canada) and irrigated using drip tape with 30-cm emitter spacing (AquaTraxx; The Toro Company, Bloomington, MN) laid under the mulch. In the low tunnel and open field treatments, plants were spaced $0.6 \mathrm{~m}$ apart in the row with $1.5 \mathrm{~m}$ between rows. Closer spacings better suited to greenhouse production were used in the high tunnel; plants were spaced $0.46 \mathrm{~m}$ apart with $1 \mathrm{~m}$ between rows, and were trellised and trained to grow vertically (Jett, 2006a). The number of plants per plot was the same for all production systems. Trellises were $2.4 \mathrm{~m}$ high and consisted of sisal twine verticals supported at the top and bottom by orchard wire laterals. Melon fruits were not supported, except by the vines. In all treatments, sufficient organic fertilizer (Pro-Gro $5 \mathrm{~N}$ 1.3P-3.3K; North Country Organics, Bradford, VT) was incorporated during planting bed construction to provide $56 \mathrm{~kg} \cdot \mathrm{ha}^{-1}$ of nitrogen. Fish emulsion (Organic Gem) was applied every 7 to $10 \mathrm{~d}$ via fertigation to provide $1.4 \mathrm{~kg} \cdot \mathrm{ha}^{-1}$ of nitrogen at each application. Irrigation totaled $2.5 \mathrm{~cm} \cdot \mathrm{week}^{-1}$. Plants were covered with insect barrier supported by $0.6-\mathrm{m}$-high galvanized wire hoops from transplanting until anthesis. The insect barrier provided protection from striped cucumber beetle (Acalymma vitattum) and the beetle-vectored bacterial wilt disease (incited by Erwinia trachephila). In $2011,15 \mathrm{~g} \cdot \mathrm{m}^{-2}$ spunbonded polypropylene (Agribon-15; Berry Plastics Corp., Evansville, IN) was used as the insect barrier; plants were covered until June 19 in all treatments. Covers were removed at the beginning of flowering to permit bees to access the flowers. In 2012, 0.85-mm polyamide mesh $\left(17 \mathrm{~g} \cdot \mathrm{m}^{-2}\right)$ (Dubois Agrinovation, QC, Canada) was used because it provided similar levels of insect protection with minimal thermal effect. In 2012, the insect barrier was removed on May 28 in the high tunnel treatment, June 12 in the low tunnel treatment, and June 27 in the open field treatment. During anthesis, plants were sprayed with a $0.4 \%$ solution of pyrethrum (Pyganic EC 5.0; Valent, Walnut Creek, CA) whenever beetle populations exceeded one beetle per two plants. In 2011, both the high tunnel and open field production systems were sprayed once, while the low tunnel production system was sprayed twice. In 2012, the open field production system was sprayed once for cucumber beetles. Honey bees were provided to ensure pollination.

Temperature loggers (Thermochron iButtons; Embedded Data Systems, Lawrenceburg, KY) were used to track air temperature within the canopy in all treatments. Canopy temperatures were recorded at $20-\mathrm{cm}$ height in the low tunnel and open field treatments. The temperature sensors in the high tunnel started at $20 \mathrm{~cm}$ height and were raised so the sensor remained at midcanopy as the plants grew, eventually reaching a height of $165 \mathrm{~cm}$. Ambient air temperatures were recorded by an on-farm weather station.

Tunnel descriptions. The high tunnel treatments were located within three Gothic-style tunnels (Nolt's Produce Supplies, Leola, PA) each measuring $22 \mathrm{~m}$ long $\times 6 \mathrm{~m}$ wide, with 1.2-m-high sidewalls and a height of $4 \mathrm{~m}$ at the peak. The tunnels were arranged in an eastwest orientation and were covered with a single layer of $0.153 \mathrm{~mm}$, 4-year Tufflite IV greenhouse polyethylene (Berry Plastics Corp.). Ventilation was provided by rollup vents on each of the long sides of the tunnel and on the roof. The roof ridge vent was automated and opened whenever air temperature at $1 \mathrm{~m}$ aboveground level within the tunnel exceeded $18{ }^{\circ} \mathrm{C}$.

The low tunnels were constructed of ventilated clear plastic placed over the insect barrier. In 2011, 0.025-mm perforated plastic (Ken-Bar, Rochester, NY) was used for the low tunnels; in 2012, 0.02-mm slitted plastic (Ken-Bar) was used. While both types of cover are self-ventilating, excessively high temperatures can occur under the plastic when external air temperatures exceed $30{ }^{\circ} \mathrm{C}$ (Wells

Table 1. Seeding and harvest dates for melons by production system and year.

\begin{tabular}{|c|c|c|c|c|c|c|}
\hline $\mathrm{Yr}$ & $\begin{array}{c}\text { Production } \\
\text { system }\end{array}$ & Seeding $^{z}$ & Transplanting & First harvest $\mathrm{t}^{\mathrm{y}}$ & Harvest period & $\begin{array}{c}\text { Total } \\
\text { harvests }\end{array}$ \\
\hline \multirow[t]{3}{*}{$\overline{2011}$} & High tunnel & 26 Apr. & 31 May & $210.4 \mathrm{a}$ & 26 July-22 Aug. & 14 \\
\hline & Low tunnel & 25 Apr. & 31 May & $211.0 \mathrm{ab}$ & 27 July-22 Aug. & 9 \\
\hline & Open field & 6 May & 31 May & $211.7 \mathrm{~b}$ & 28 July-22 Aug. & 9 \\
\hline \multirow[t]{3}{*}{2012} & High tunnel & 18 Apr. & 16 May & $195.9 \mathrm{a}$ & 9 July-7 Aug. & 13 \\
\hline & Low tunnel & 2 May & 26 May & $202.7 \mathrm{~b}$ & 18 July-9 Aug. & 10 \\
\hline & Open field & 14 May & 9 June & $214.1 \mathrm{c}$ & 25 July-16 Aug. & 9 \\
\hline
\end{tabular}

${ }^{\mathrm{z}}$ Average last frost at the Gardiner Crops Research Center is 15 May, but cool, wet spring weather can result in CI to unprotected cucurbit transplants before early June. In 2011, the initial set of seedlings, started 15 Apr., had to be replaced because the high tunnels were not available in time for transplanting until 31 May.

${ }^{\mathrm{y}}$ The day of the year of first harvest, averaged across all cultivars $(n=30)$. Letters indicate statistical significance within year at $P<0.05$.

and Loy, 1993). The risk of extreme temperatures is greater with perforated plastic, as it traps more heat during the day than slitted plastic (Wells and Loy, 1993). In 2011, the perforated plastic covers were removed to vent excess heat from the tunnels when ambient air temperatures exceeded $30{ }^{\circ} \mathrm{C}$; this was not necessary in 2012 due to cooler conditions and use of slitted plastic. Covers were removed late morning, and replaced in late afternoon when ambient air temperatures dropped below $30^{\circ} \mathrm{C}$.

Experimental design and response variables. The experimental design was a randomized complete split-plot design with six replications. The three production systems (high tunnel, low tunnel, and open field) formed the main plots, with the five melon cultivars as the subplots. Each replication of each main plot contained 25 plants, with 5 in each subplot. The basic statistical model for analysis of variance (ANOVA) was the full polynomial for the three-way interaction of year $\times$ production system $\times$ cultivar, but since all interactions involving year were significant, the data for 2011 and 2012 were analyzed separately. Response variables evaluated were date of first harvest, fruit yield, and fruit quality. To determine yield, fruit were graded into marketable and cull, and then counted and weighed. Fruit were harvested at full slip, except for 'Sivan' which was harvested at half-slip. Fruit were considered marketable if rind color, netting, and fruit size were normal for the cultivar, and the fruit were not cracked, damaged, or diseased. Marketable fruit were not further separated into grades, as this is not a common practice for local markets. Soluble solids measured with a handheld refractometer (Ade Advanced Optics, Oregon City, OR) following MacGillivray (1947) were used as an indicator of fruit quality. A soluble solids content of $9 \%$ was the minimum acceptable sweetness (Agricultural Marketing Services, 2008). The first three marketable crown fruits to ripen in each plot were used for soluble solids testing. Samples were collected by cutting the fruit in half lengthwise, then sampling at four or six equidistant locations on the bottom half of the fruit. The number of samples depended on the size of the fruit, with larger fruits sampled at six locations. Soluble solids were measured separately on each sample, and the average of the samples was used to represent the fruit, to account for variation in sugar content within the fruit. The data were analyzed by ANOVA and means separation was by Fisher's protected least significant difference at $P \leq 0.05$. Harvest distributions were compared using the Kolmorogov-Smirnov test. Data analysis was done using SAS version 9.2 (SAS Institute, Cary, NC).

\section{Results}

\section{Effects of tunnels on temperature}

Soil temperatures within the melon root zone were similar across production systems in 2011 , with daily means of $23.4,23.2$, and $23.2{ }^{\circ} \mathrm{C}$ in the high tunnels, low tunnels, and open field, respectively. In 2012, the root-zone 
soil temperature in the high tunnels averaged $21.9{ }^{\circ} \mathrm{C}$ from transplanting until harvest. Root-zone soil temperatures in the low tunnels averaged $24.4^{\circ} \mathrm{C}$ while the covers were in place, and $25.6{ }^{\circ} \mathrm{C}$ from cover removal until the beginning of harvest. In 2012, rootzone soil temperatures in the open field averaged $25.2^{\circ} \mathrm{C}$. GDD from transplanting until the beginning of harvest were calculated for each production system from canopy air temperatures with a base of $14{ }^{\circ} \mathrm{C}$ and a maximum temperature of $40^{\circ} \mathrm{C}$ (Jenni et al., 1996). Total GDD for each production system and year are presented in Table 2 .

The 2011 production season was warm, with an average daily high of $32^{\circ} \mathrm{C}$, and a low of $15{ }^{\circ} \mathrm{C}$. Based on temperatures at the weather station (ambient open air), 140 GDD accumulated from melon transplanting until the covers were removed on June 21 (beginning of flowering), and an additional 379 GDD accumulated from cover removal until the beginning of harvest on 26 July. In the open field treatment, the spun-bonded insect barrier resulted in an increased heat accumulation of 39 GDD over ambient from transplanting until cover removal. During the same period, the low tunnels increased heat accumulation by 97 GDD over ambient. The open field treatment accumulated 582 GDD by the beginning of harvest on 28 July. Harvest began on 27 July in the low tunnel treatment, at which point 598 GDD had accumulated. The high tunnel treatment accumulated a total of 549 GDD from transplanting until harvest began on 26 July.

During the 3 weeks that the low tunnel treatment was covered, the average air temperature under the covers was $24.6{ }^{\circ} \mathrm{C}$, compared with $22.9^{\circ}$ under the Agribon- 15 insect barrier in the open field treatment, and $23.0^{\circ} \mathrm{C}$ in the high tunnels. The low tunnels had greater variation in air temperature, with an average daily high of $42.4{ }^{\circ} \mathrm{C}$ and an average daily low of $13.0{ }^{\circ} \mathrm{C}$, as compared with average values of 33.4 and $14.8{ }^{\circ} \mathrm{C}$, respectively, in the high tunnels and 28.9 and $12.1{ }^{\circ} \mathrm{C}$, respectively, in the open at the weather station. When the ambient air temperature exceeded $30{ }^{\circ} \mathrm{C}$, temperatures in the low tunnels regularly exceeded $40{ }^{\circ} \mathrm{C}$ in the middle of the day despite the perforated plastic covers being removed. From 19 June until the beginning of harvest, the average air temperatures were $24.0^{\circ} \mathrm{C}$ in the high tunnels and $24.2{ }^{\circ} \mathrm{C}$ in the low tunnel and open field treatments.

The 2012 production season was cooler than 2011 , with an average high of $27^{\circ} \mathrm{C}$ and an average low of $14{ }^{\circ} \mathrm{C}$. Transplanting and harvest dates differed by production system, with the high tunnels being planted first. Growers in New England regularly use high tunnels to plant crops earlier than are recommended for open field planting, in hopes of getting an earlier harvest and capturing the associated price premium in the market (Carey et al., 2009). In addition to increasing air temperature (and growth) in the crop canopy, high tunnels protect crops from chilling spring rains, which can rapidly lower soil temperatures. Based on ambient air temperatures at the weather station, 324 GDD accumulated during the high tunnel production period in 2012, 405 GDD accumulated during the low tunnel production period, and 493 GDD accumulated during the open field production period. GDD accumulation was measured from transplanting until the beginning of harvest for each production treatment. The low tunnels were in place for $18 \mathrm{~d}$ and increased heat accumulation by 164 GDD relative to ambient. The mesh insect barrier increased heat accumulation by only 28 GDD relative to ambient. Once the covers were removed, the low tunnel and open field treatments accumulated GDD at the ambient rate. The high tunnels increased heat accumulation by 86 GDD relative to ambient in the $12 \mathrm{~d}$ between transplanting and flowering, and by 184 GDD relative to ambient from transplanting until the beginning of harvest in 2012.

During the period from transplanting until harvest, air temperatures in the high tunnels averaged $23{ }^{\circ} \mathrm{C}$, with an average daily high temperature of $31.0^{\circ} \mathrm{C}$ and an average overnight low temperature of $14.9^{\circ} \mathrm{C}$. The lowest temperature recorded in the high tunnels was $6.8^{\circ} \mathrm{C}$, on a night when the outside temperature dropped to $3.9^{\circ} \mathrm{C}$. The air temperature in the low tunnels averaged $24.6^{\circ} \mathrm{C}$ while the covers were in place, with an average daily high temperature of $41.6^{\circ} \mathrm{C}$ and an average

Table 2. Thermal units $\left[{ }^{\circ} \mathrm{C}\right.$ growing degree-days (GDD)] by treatment and year with a maximum high temperature of $40{ }^{\circ} \mathrm{C}$ and a base of $14^{\circ} \mathrm{C}$.

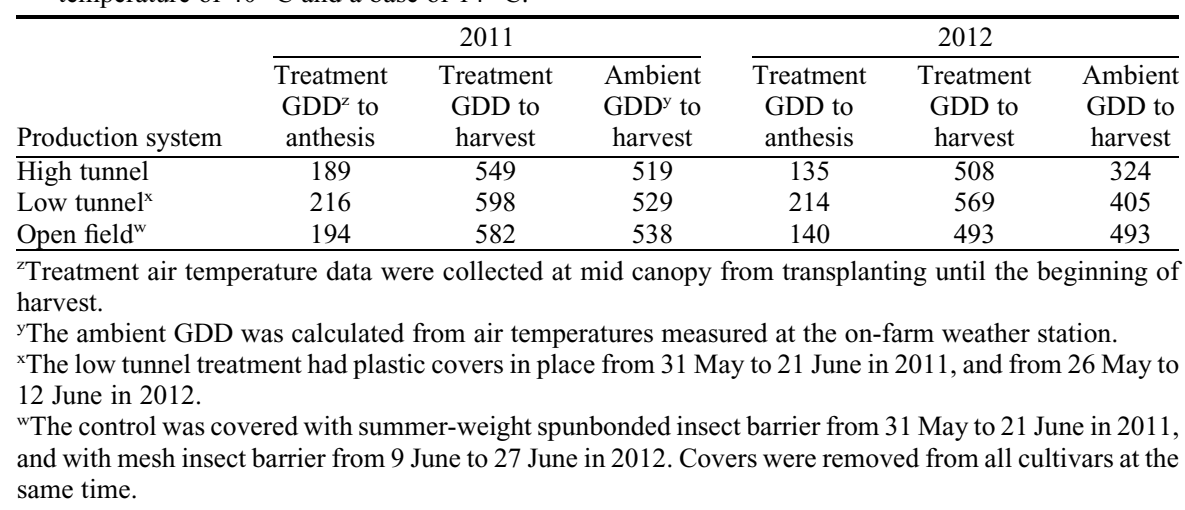

overnight low temperature of $14.6{ }^{\circ} \mathrm{C}$. In the open field treatment, the average daily high temperature under the insect barriers was $31.8{ }^{\circ} \mathrm{C}$ and the average overnight low was $15.1^{\circ} \mathrm{C}$. Once the covers were removed, the average daily high temperature in the low tunnel and open field treatments was $33.3^{\circ} \mathrm{C}$, and the average overnight low temperature was $15.6{ }^{\circ} \mathrm{C}$.

\section{Earliness and distribution of fruit harvest}

Production system and cultivar both significantly affected the date of first fruit harvest. The order of ripening was the same in both years, with the high tunnel system being the first to produce ripe fruit and the open field system the last (Table 1). In 2011, the first high tunnel fruit ripened an average $1.3 \mathrm{~d}$ earlier than in the open field; in 2012, the difference was $18.2 \mathrm{~d}$. The first low tunnel fruit ripened only $0.7 \mathrm{~d}$ earlier on average than the open field in 2011, despite the plants in the low tunnel production system having been seeded $11 \mathrm{~d}$ earlier. In 2012, the difference in seeding dates was $12 \mathrm{~d}$ between the low tunnel and the open field production systems, and the first low tunnel fruit ripened $11.2 \mathrm{~d}$ earlier than the first fruit in the open field. The effects of production system on fruit ripening were consistent across all cultivars. Cultivars ripened in the order Sarah's Choice < Sivan $<$ Lil' Loupe $<$ Athena $<$ Tasty Bites in 2011, and Sarah's Choice $<$ Sivan $<$ Tasty Bites $<$ Lil' Loupe $<$ Athena in 2012.

In 2011, the fruit harvest period lasted for 5 weeks in all three production systems. Harvest peaked during week two in all systems (Fig. 1). In 2012, greater separation of planting and transplanting dates resulted in a greater difference in time to peak yield among the production systems. The harvest period lasted a total of 6 weeks, with the high tunnel system harvested in weeks $1-5$, the low tunnel system in weeks $2-5$, and the open field system in weeks 3-6 (Fig. 1). Harvest peaked in the second week for the high tunnel system, and in the middle 2 weeks for the low tunnel and open field systems. The Kolmogorov-Smirnov two-sample test was used to compare the harvest distributions among production systems. This test compares the shapes of the distribution curves, rather than the actual values, so it is unaffected by differences in total yield or in earliness. The distribution of fruit yield over time in the high tunnel system was significantly more uniform $(P<0.01)$ than in the low tunnel and open field systems in both years (Fig. 1). The low tunnel system was significantly $(P<0.001)$ less uniform than the open field system for distribution of fruit yield over time in 2012, but not in 2011 $(P=0.07)$.

Quality. In melons, fruit quality is largely determined by sugar levels, which may be positively correlated with soluble solids (Chace et al., 1924). Obtaining high soluble solids level is challenging under New England conditions, where melons are prone to 

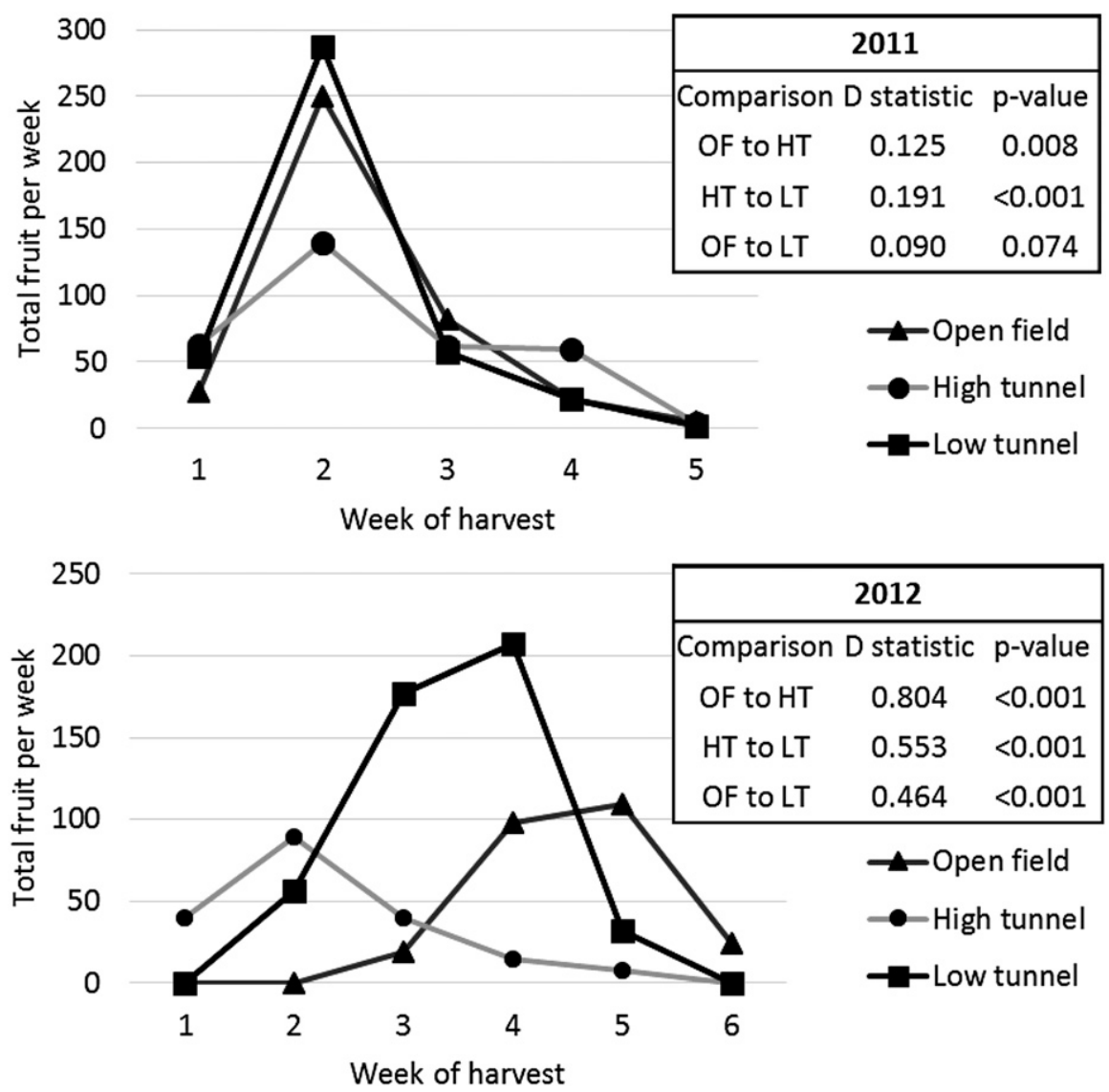

Fig. 1. Distribution of melon fruit harvest by week for open field (OF), high tunnel (HT), and low tunnel (LT) production systems in 2011 and 2012. Harvest dates are given in Table 1. Distributions were compared using the Kolmorogov-Smirnov two-sample test.

severe wilting of the vines in the days before harvest (Loy, 2013). The low tunnel production system produced the sweetest fruit in both years, averaging $10.7 \%$ total soluble solids (TSS) in 2011 and $9.6 \%$ TSS in 2012. Low tunnel fruit quality based on TSS was significantly better $(P<0.01)$ than high tunnel fruit quality in both years, and significantly better $(P<0.005)$ than the quality of the fruit from the open field in 2012. High tunnel fruit averaged $8.8 \%$ TSS in 2011 and $8.0 \%$ TSS in 2012 while fruit from the open field averaged $9.9 \%$ TSS in 2011 and $7.4 \%$ in 2012. Treatment effects were consistent across cultivars in both years.

Fruit quality based on TSS differed significantly between cultivars in 2012, but not in 2011. Mean TSS values for the first three marketable fruit harvested per plot in 2011 ranged from $9.4 \%$ TSS for 'Lil' Loupe' to $10.1 \%$ TSS for 'Sarah's Choice'. In 2012, the mean TSS values for the first three marketable fruit harvested per plot ranged from $7.4 \%$ TSS for 'Sivan' to $9.9 \%$ TSS for 'Sarah's Choice'. Sarah's Choice had significantly $(P<0.005)$ greater \% TSS than any of the other cultivars in 2012. Summary statistics for all cultivar $\times$ production system interactions for TSS are given in Table 3 . Within each cultivar, fruit quality varied widely even though all fruits sampled appeared to be fully ripe based on rind color, netting, and extent of slip. For 'Sarah's Choice', the 2011 TSS values ranged from a low of $8.0 \%$ TSS in the high tunnel production system to a high of $13.5 \%$ TSS in the low tunnel production system. In 2012, the range was even greater, with a low of $6.3 \%$ TSS in the high tunnel production system and a high of $13.4 \%$ TSS in the low tunnel production system. 'Sivan' was particularly variable, with both the highest fruit quality $(13.7 \%$ TSS in the open field in 2011) and the lowest fruit quality (5.0\% TSS in both the open field and the high tunnel in 2012).

\section{Total fruit production}

Determination of yields per hectare for high tunnel studies is complicated. Even the largest high tunnels contain less than a hectare of growing space, so multiple tunnels would be required. The amount of actual growing space in a hectare of high tunnels is strongly affected by the size and shape of the tunnels, and the spacing between tunnels. The optimal size, shape, and between-tunnel spacing depend on the climate, the latitude, and the season(s) during which the tunnels will be used for crop production (Blomgren and Frisch, 2007). For simplicity, yield and cost calculations presented here are based actual growing space, not total space occupied by high tunnels.

In this study, the use of close in-row spacing and trellising permitted a population of 21,739 plants per hectare in the high tunnel production system, while the open field and low tunnel systems had only 11,111 plants per hectare. The increased planting density resulted in total yields of 47,246 fruit per hectare in the high tunnel production system in 2011, which was significantly $(P=0.0001)$ more than the 31,111 fruit per hectare produced in the low tunnel production system and the 28,444 fruit per hectare in the open field production system (Fig. 3). However, in the 2011 trial, the high tunnel produced only 2.2 fruit per plant, which was significantly less $(P<0.05)$ than the 2.8 fruit per plant produced in the low tunnel production system.

In 2012 , the production system $\times$ cultivar interaction was significant for fruit yields, and the rank order of fruit yields in the production systems varied by cultivar (Fig. 2). The low tunnel production system yielded significantly more fruit per hectare than the other systems for the cultivars Lil' Loupe, Sivan, and Tasty Bites. The high tunnel production system yielded the most fruit per hectare for 'Athena' and 'Sarah's Choice'. However, the low tunnel production system yielded significantly more fruit per plant than the other production systems across all five cultivars, with a production system average of 3.1 fruits per plant, as compared with 1.4 fruits per plant in the high tunnel production system and 1.7 fruits per plant in the open field.

When yields were analyzed in terms of fruit weight, rather than number of fruit, the production system $\times$ cultivar interaction was significant $(P<0.05)$ in both 2011 and 2012; as a result, data are summarized by cultivar for each year (Fig. 3). In 2011, the high tunnel production system yielded significantly $(P<$ 0.05 ) more weight per unit area than the other production systems for all cultivars except Sivan. The low tunnel and open field production systems had similar yields for all cultivars in 2011. 'Athena' and 'Sarah's Choice' produced similar yields per unit area in the high tunnel and low tunnel production systems in 2012; both systems had significantly higher $(P<0.05)$ yields than in the open field. 'Lil' Loupe', 'Sivan', and 'Tasty Bites' all yielded significantly more $(P<$ $0.05)$ in the low tunnel system than in either the high tunnel or open field systems in 2012. High tunnel yields for these cultivars were similar to open field yields.

\section{Marketable yields}

Increasing total yields, either per unit area or per plant, is useful only if marketable yields also increase. Fruit were classified as marketable if the rind was not damaged and rind color, netting, and size were within the expected range for the cultivar. Percent total soluble solids were not considered when determining marketability, as it was not possible to test every fruit. In 2011, the percentage of the total yield that was marketable differed among cultivars, but not among production systems. Production system means were $70 \%$ marketable fruit for the open field, $75 \%$ marketable field for the low tunnel, and $76 \%$ marketable fruit for the high tunnel. Athena had a significantly higher $(P<0.05)$ percentage of 


\begin{tabular}{|c|c|c|c|c|c|c|c|c|c|}
\hline \multirow[b]{3}{*}{ Production system } & \multirow[b]{3}{*}{ Cultivar } & \multicolumn{4}{|c|}{2011} & \multicolumn{4}{|c|}{2012} \\
\hline & & \multicolumn{2}{|c|}{$\% \mathrm{TSS}^{\mathrm{z}}$} & \multirow[b]{2}{*}{ Fruit size $(\mathrm{kg})^{\mathrm{y}}$} & \multirow[b]{2}{*}{ Fruit per plant } & \multicolumn{2}{|c|}{$\% \mathrm{TSS}$} & \multirow[b]{2}{*}{ Fruit size $(\mathrm{kg})$} & \multirow[b]{2}{*}{ Fruit per plant } \\
\hline & & Mean & Range & & & Mean & Range & & \\
\hline \multirow[t]{5}{*}{ Low tunnel } & Athena & 10.2 & $9.4-10.8$ & 1.5 & 2.0 & 9.3 & $7.2-11.9$ & 1.6 & 2.3 \\
\hline & Lil' Loupe & 10.4 & $9.6-11.3$ & 0.8 & 3.4 & 9.7 & $7.6-10.5$ & 0.8 & 3.7 \\
\hline & Sarah's Choice & 11.2 & $9.9-13.5$ & 1.4 & 2.3 & 11.9 & $6.9-13.4$ & 1.2 & 2.7 \\
\hline & Sivan & 11.2 & $9.5-12.5$ & 0.7 & 3.0 & 8.8 & $7.2-9.6$ & 0.7 & 3.2 \\
\hline & Tasty Bites & 10.3 & $7.9-11.9$ & 0.6 & 3.5 & 8.4 & $6.4-10.8$ & 0.5 & 3.8 \\
\hline \multirow[t]{5}{*}{ High tunnel } & Athena & 8.8 & $6.5-10.6$ & 1.8 & 1.9 & 8.5 & $7.6-9.8$ & 1.2 & 1.5 \\
\hline & Lil' Loupe & 8.5 & $6.1-11.3$ & 1.1 & 2.7 & 7.9 & $6.1-9.7$ & 0.6 & 1.3 \\
\hline & Sarah's Choice & 9.2 & $8.0-11.0$ & 1.5 & 2.2 & 8.9 & $6.4-11.4$ & 1.0 & 1.8 \\
\hline & Sivan & 8.0 & $5.7-11.0$ & 0.9 & 1.7 & 7.2 & $5.0-10.2$ & 0.5 & 0.8 \\
\hline & Tasty Bites & 9.5 & $6.9-13.3$ & 0.7 & 2.3 & 7.6 & $5.4-9.9$ & 0.3 & 1.5 \\
\hline \multirow[t]{5}{*}{ Open field } & Athena & 10.9 & $9.7-11.7$ & 1.6 & 2.0 & 7.3 & $6.3-8.2$ & 1.6 & 1.0 \\
\hline & Lil' Loupe & 9.1 & $7.9-10.3$ & 0.8 & 3.2 & 6.6 & $5.2-7.9$ & 0.9 & 1.9 \\
\hline & Sarah's Choice & 9.9 & $8.0-11.9$ & 1.5 & 1.9 & 9.0 & $6.9-10.5$ & 1.3 & 1.8 \\
\hline & Sivan & 9.9 & $6.8-13.7$ & 0.8 & 2.2 & 6.2 & $5.0-7.8$ & 0.8 & 1.8 \\
\hline & Tasty Bites & 9.6 & $6.2-13.1$ & 0.6 & 3.5 & 7.9 & $7.2-8.6$ & 0.5 & 1.8 \\
\hline
\end{tabular}

${ }^{\mathrm{z}}$ TSS values are based on the first three marketable fruit harvested from each plot, with each cultivar $\times$ production system represented by six plots.

${ }^{\mathrm{y}}$ Fruit size and fruit per plant are based on total fruit, including unmarketable fruit.
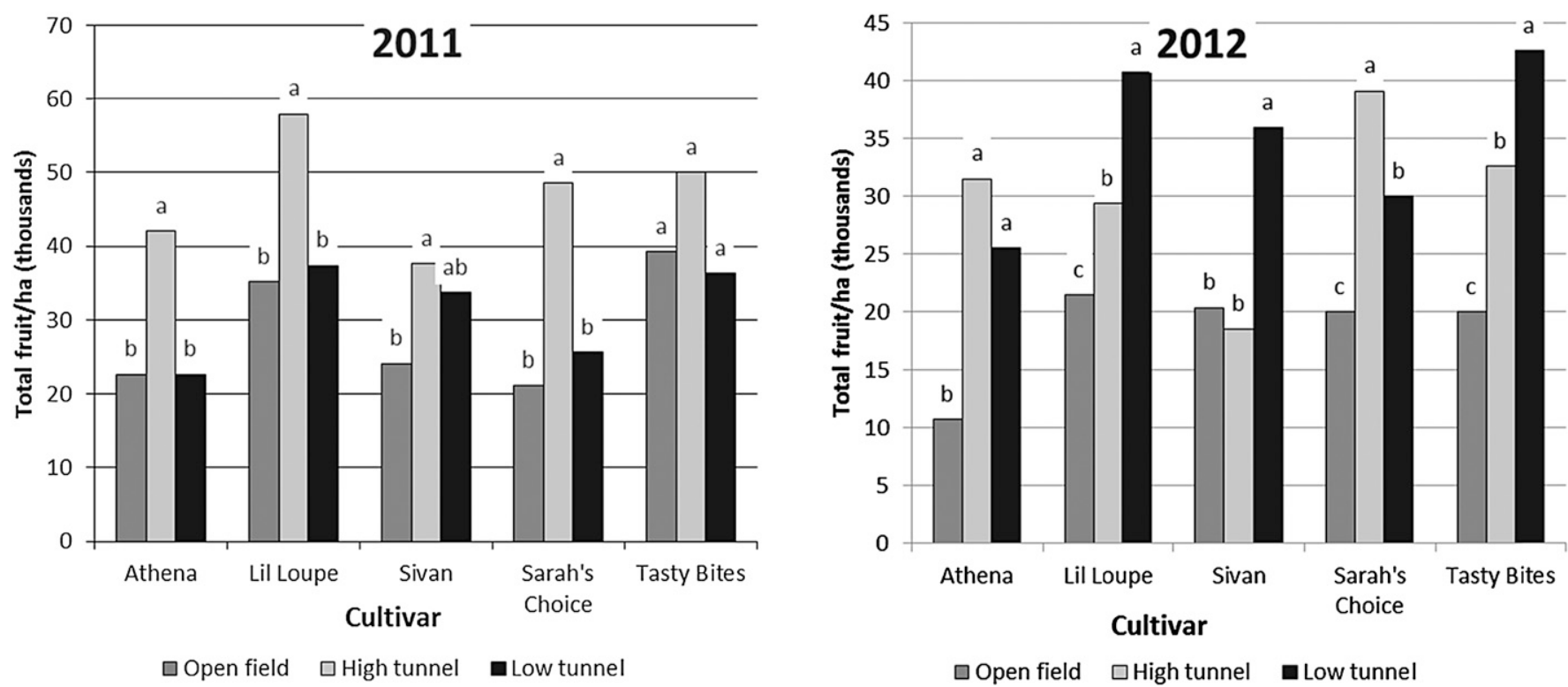

Fig. 2. Influence of production system on total yields of melons expressed as number of fruit per hectare. Data are averages across six replications. The high tunnel production system had twice as many plants per hectare as the other systems. Columns within a cultivar with the same letter did not differ significantly at $P<0.05$.

marketable fruit $(96 \%)$ than the other cultivars. 'Sivan', 'Lil' Loupe', and 'Sarah's Choice' were similar with $76 \%, 82 \%$, and $83 \%$ of fruit marketable, respectively. Tasty Bites was significantly poorer $(P<0.0001)$ than the other cultivars with only $34 \%$ of fruit being marketable. 'Tasty Bites' does not appear to be well suited to production conditions in Rhode Island, as the vines frequently wilt just as the fruit begin ripening. In 2012, both cultivar and production system significantly affected the percentage of fruit that were marketable, and the interaction between these effects was also significant $(P<0.0001)$. There were no significant differences among production systems for 'Athena', and 'Lil' Loupe', which did well in all production systems, or for 'Tasty Bites', which did poorly in all systems. These cultivars averaged $89 \%$, $87 \%$, and $74 \%$ marketable fruit, respectively. 'Sivan' had a significantly greater $(P<0.005)$ percentage marketable fruit in the high tunnel (93\%) and low tunnel (83\%) production systems than in the open field (64\%) production system, where fruit cracking was problematic. 'Sarah's Choice' had a significantly lower $(P<0.0001)$ percentage of marketable fruit in the high tunnel production system $(60 \%)$, than in the low tunnel (94\%) and open field $(88 \%)$ systems.

The production system $\times$ cultivar interaction significantly $(P<0.005)$ affected actual marketable yield in both years. In 2011, the high tunnel produced significantly greater $(P<0.05)$ marketable yields than the open field for all cultivars except Tasty Bites (Fig. 3). High tunnel yields were significantly greater than low tunnel yields in 'Athena', 'Lil' Loupe', and 'Sarah's Choice'. In 2012, the low tunnel system produced the highest marketable yields for all cultivars (Fig. 3). Low tunnel yields were significantly higher
$(P<0.05)$ than open field yields for all cultivars, and significantly higher $(P<0.05)$ than high tunnel yields in Lil' Loupe, Sivan, and Sarah's Choice. High tunnel yields differed significantly from open field yields only in 'Athena' $(P<0.0001)$.

\section{Discussion}

Vegetable growers use high tunnels and low tunnels for many purposes. For heatloving crops such as muskmelons that are grown during the normal production season, high tunnels provide protection from rainfall, may provide protection from insect pests, facilitate trellising to increase production per unit area by using vertical space, and can increase temperatures in the crop canopy, resulting in earlier harvest, greater plant growth, or higher quality fruit (Carey et al., 2009; Jett, 2006a). However, high tunnels 

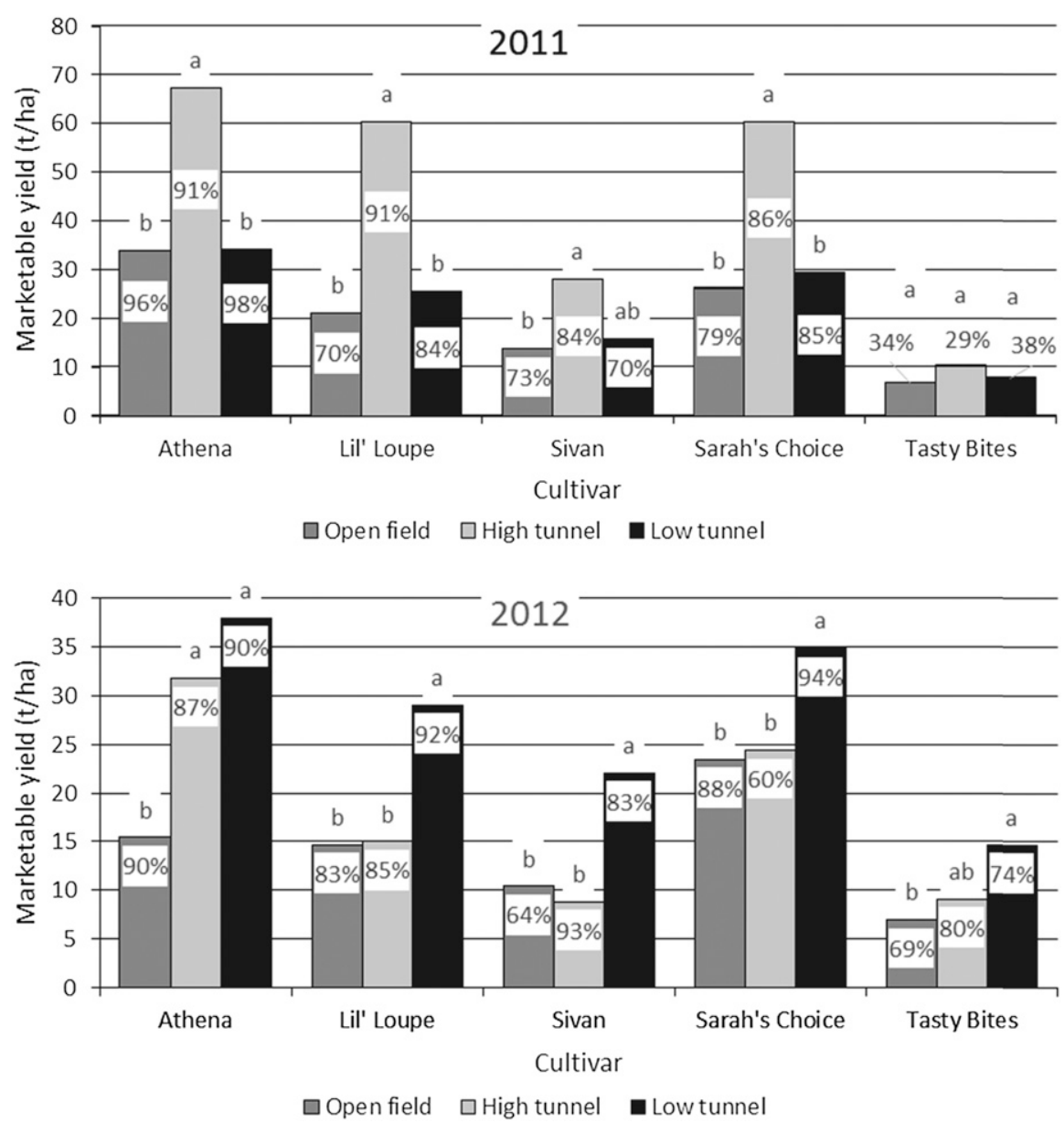

Fig. 3. Influence of production system and cultivar on marketable yields of melons in $\mathrm{kg} \cdot \mathrm{ha}^{-1}$. Data are averages across six replications. The high tunnel production system had twice as many plants per hectare as the other systems. Data labels within columns indicate the percentage of the total yield that was marketable. Labels above the columns indicate significance at $P<0.05$; columns within a cultivar with the same letter did not differ significantly.

also create challenges. In addition to the costs of the structures themselves, additional labor is required to train and prune trellised crops (Lamb et al., 2003; Shaw et al., 2004). Insects such as aphids, whiteflies, thrips, and mites are more likely to reach damaging levels in high tunnels than in the open field, and pruning trellised crops can spread diseases (Blomgren and Frisch, 2007). Growers use low tunnels to increase temperatures during vegetative growth of heat-loving crops, which can decrease time to flowering, resulting in earlier harvest. By promoting early season growth, low tunnels may increase plant size at flowering, resulting in increased photosynthetic capacity which will support higher yields and increased quality (Lamont, 1996). Depending on the type of covers used, low tunnels can also provide protection from cold night temperatures, or from insect pests (Wells and Loy, 1993). Low tunnels cost less than high tunnels, and generally require less labor. However, they do not provide protection during reproductive growth of crops, and the smaller volume of air under low tunnels increases the risks of excessively high temperatures in the canopy relative to high tunnels.
In this study, the use of ventilated clear plastic low tunnels increased marketable yield and quality of the initial flush of marketable fruit relative to the open field in both 2011 and 2012. The greater impacts of the low tunnels in 2012 are likely due to the cooler ambient temperatures that year, and the earlier planting date made possible by the low tunnels, which translated to earlier harvest and enabled plants in the low tunnel production system to escape damage from heavy rains and fungal disease in August. In 2011, the warmer ambient air temperatures and the slight heat trapping effects of the summer-weight spunbonded insect barrier combined to reduce differences between the low tunnels and the open field. Loy and Wells (1982) showed that while temperatures were lower under spunbonded polyester covers than under clear slitted plastic, muskmelon yields were statistically similar in the two systems, and actually slightly higher under the spunbonded polyester covers. However, they appear to have been using covers that were heavier than the ones used in this study. The use of ventilated clear plastic low tunnels increases the cost of production by an estimated \$5000/ha over the open field system. Based on farmers market prices of $\$ 1.76 / \mathrm{kg}$ a $15 \%$ increase in yield would be required to offset the increased costs of using low tunnels (R. Brown, unpublished data). This was achieved in 2012, but not in 2011. The estimated costs of the low tunnel production system include annual expenses for wire hoops and slitted plastic covers, as well as increased labor (Baker et al., 2000; Woods, 2013). Labor calculations used the $\$ 10 / \mathrm{h}$ wage common for seasonal farm workers in southern New England.

The closer plant spacing possible in the trellised high tunnel production system significantly increased both total and marketable yields relative to the low tunnel and open field systems in 2011, and relative to the open field system in 2012. However, this increase in yields was accompanied by a substantial increase in production costs. High tunnel production is estimated to cost $\$ 8.61 / \mathrm{m}^{2}$ more than open field production if the high tunnels are also used to grow a winter vegetable crop, and $\$ 10.32 / \mathrm{m}^{2}$ more if the structures are used only for melons. Average high tunnel yields in $\mathrm{kg} \cdot \mathrm{ha}^{-1}$ were more than double the open field yields in 2011, but only 25\% higher in 2012 . The largest yield difference in our study was for 'Lil' Loupe' in 2011, when the marketable yield from the high tunnel was $287 \%$ of that from the high tunnel. Based on the typical Rhode Island farmers market price of $\$ 1.76 / \mathrm{kg}$ for melons the increased yield from the high tunnel would only be worth just over $\$ 6.90 / \mathrm{m}^{2}$, which is insufficient to offset the increased costs of the high tunnel production system. Structure costs were calculated assuming a 10 -year life span for the high tunnel frame and a 4-year useful life for the plastic cover. Labor costs were calculated from the enterprise budget for trellised Galia muskmelons by Shaw et al. (2004) using the $\$ 10 / \mathrm{h}$ wage common for seasonal farm workers in southern New England.

The primary effect of tunnels in melon production is to increase daytime air temperatures in the canopy. High tunnels can also protect against cold rains and, as reported in this study, increase nighttime temperatures by an average of $2.7^{\circ} \mathrm{C}$ above ambient air temperatures. Neither single-layer high tunnels nor clear plastic rowcovers will reliably protect melons against late frosts. Melon growth rate is affected by temperature, with a maximum of 0.7 to 0.8 nodes produced per day at $34{ }^{\circ} \mathrm{C}$. Growth rate increases linearly with temperature from 10 to $34{ }^{\circ} \mathrm{C}$ and then decreases as temperatures increase to $45^{\circ} \mathrm{C}$ (Baker and Reddy, 2001). Anthesis is triggered by a combination of plant size and additional factors such that the thermal units required to produce mature fruit vary depending on planting date, cultivar, and location (Baker et al., 2001; Jenni et al., 1996).

Increasing the temperature during vegetative growth may decrease the time from planting to anthesis, but it appears to more often result in larger plants at anthesis, which may lead to increased yields and quality due to increased photosynthetic capacity (Bonanno and Lamont, 1987). The effects of increasing temperature during fruit development are less 
understood, in part because most studies have used rowcovers, which are removed at anthesis (Jenni et al., 1996). Under the cool climate of Saskatchewan, melons grown in high tunnels accumulated $\times 1.3$ more heat units following anthesis than melons grown in low tunnels and ripened 2 to 3 weeks earlier (Waterer, 2003).

The earlier planting and transplanting dates possible with both low and high tunnels did result in earlier harvests in this study despite increased time from planting to harvest relative to the open field (Table 1). These results agree with those of Loy and Wells (1975), who found that polyethylene rowcovers resulted in earlier flowering in melons, but fruit took longer to mature because temperatures were cooler during fruit development for early flowering plants than when plants flowered at the normal time. Other researchers have found that earlier harvests with covered cultivation are primarily due to earlier planting dates (Bonanno and Lamont, 1987; Jett, 2006b). In our study in 2012, the high tunnels accumulated $\times 2.7$ more heat units than the open field in the first 2 weeks after transplanting, but only $\times 1.8$ more in weeks 3 and 4, which were the 2 weeks immediately following transplanting into the low tunnels. By the time the open field plots were planted, the high tunnel was only accumulating heat units $\times 1.4$ as fast as the open field. In 2011, the combination of warmer weather and the later transplanting date meant that the high tunnel never accumulated heat units at more than $\times 1.4$ the rate in the open field. These results suggest that tunnels are most effective for shortening time to maturity when temperatures in the open are below the midpoint of the optimal range. High tunnels can be expected to out-perform low tunnels when temperatures in the open remain low for the entire growing season, as Waterer (2003) found in Canada.

Many researchers have shown that melon fruit quality is extremely sensitive to plant health and environmental factors in the final $10 \mathrm{~d}$ before full ripeness (Bianco and Pratt, 1977; Bouwkamp et al., 1978; Lingle and Dunlap, 1987). Melon growth is optimal when temperatures are within the range of 30 to $35^{\circ} \mathrm{C}$ (Hartz et al., 2008). The effect of air temperature on fruit quality as determined by $\%$ TSS is complicated by the effects of solar radiation on both photosynthetic output of the plant and respiration rate within the fruit itself (Bouwkamp et al., 1978). In 2011, the average daily high temperature during the harvest period was $32.4^{\circ} \mathrm{C}$, and the weather was dry with abundant solar radiation. In contrast, in 2012, average daily high temperatures averaged $29.4{ }^{\circ} \mathrm{C}$ during harvest for all treatments, with frequent clouds and rainfall. Rainfall particularly affected the control treatment in 2012, as a week of rain preceded peak harvest. The high tunnel treatment had passed peak harvest, and the low tunnel treatment was at peak harvest, when the rains began. Wells and Nugent (1980) reported that soluble solids were negatively correlated with soil moisture in the week before harvest.
Suboptimal fruit quality is a common problem with melon production in New England, and was one of the reasons for conducting this study.

The low tunnel production system produced the highest quality fruit in both years. The ability of low tunnels to increase fruit quality is likely a result of increased leaf canopy size in the low tunnel relative to the open field. Melon plants with larger canopies have been shown to produce sweeter fruit because of the increased ability to photosynthesize and translocate sugars to the fruit (Kultur et al., 2001). Quality of the first three marketable fruit (measured as total soluble solids) was significantly lower in the high tunnel than in the low tunnel production system in both years, and marketable yields were significantly lower than the low tunnel production system in 2012. Both fruit yields and fruit quality for high tunnel melons in this study were lower than reported in other studies (Lamb et al., 2003; Rodriguez et al., 2007), and were generally unacceptable. Melons can be successfully grown in passively ventilated greenhouses, as has been shown by Lamb et al. (2003) and Rodriguez et al. (2007), in Florida. Greenhouse production of melons is a common practice in the Mediterranean, particularly in the Andalusia region of Spain (Tout, 1990). However, most greenhouse production uses Galia or Piel de Sapo melon cultivars developed for protected culture, rather than the American cantaloupe cultivars used in this study, which were developed for open field production. In addition, while the plant density used in this study was within the range shown not to affect marketable yields or soluble solids in trellised production in Florida (Rodriguez et al., 2007), the greenhouse production systems in both Florida and Spain use soilless culture, growing the melons either in perlite or in sand. It is possible that greater spacing is needed when growing in soil, or that the melon cultivars used in this study were not well suited to trellised production in high tunnels. It is also possible that the melons in this study were not pruned sufficiently, as they developed large canopies which have been shown to reduce yields in trellised melons (Lamb et al., 2003). Disease and insect problems were noticeably greater in the high tunnel production system relative to the low tunnels and open field. The extended fruiting time for the high tunnel melons may also have weakened the plants, as was reported by Waterer (2003).

Wholesale growers will harvest a melon planting for only 10-14 d before moving to the next field (Hartz et al., 2008). However, market growers may seek to extend the harvest period to meet customer demand, increase yields per plant, and avoid the complexities of managing succession plantings. In Florida, trellised Galia melons averaged five fruits per plant, at $1.2 \mathrm{~kg} /$ fruit, over a 7 to 10 week harvest season (Rodriguez et al., 2007). Our results show that growing muskmelons in high tunnels is effective for extending the harvest period and increasing yields per unit area, but not at increasing yields per plant.
In conclusion, low tunnels are a costeffective practice for improving yields and quality for melons in southern New England, with potential to double yields. They are particularly effective in years or locations where the average daytime temperature during the summer is below $35^{\circ} \mathrm{C}$. Low tunnels also have the potential to permit earlier transplanting, although this is limited by the risk of lethal chilling injury on cloudy days or at night. The results of this study suggest that the American cantaloupe melons popular in New England markets are not well suited to high tunnel production, and that intensive greenhouse production techniques may be necessary to grow trellised melons in high tunnels without sacrificing yields and fruit quality. In the absence of such systems for American cantaloupes, the high cost space in high tunnels is better used for crops such as tomatoes and cucumbers where the longer harvest period can greatly increase yields per plant over field production.

\section{Literature Cited}

Agricultural Marketing Services. 2008. United States standards for grades of cantaloupes. U.S. Dept. Agr., Washington, DC.

Baker, J.T., D.I. Leskovar, V.R. Reddy, and F.J. Dainello. 2001. A simple phenological model of muskmelon development. Ann. Bot. 87: 615-621.

Baker, J.T. and V.R. Reddy. 2001. Temperature effects on phenological development and yield of muskmelon. Ann. Bot. 87:605-613.

Baker, L.B.B., J.C. Henning, S. Jenni, and K.A. Stewart. 2000. An economic and energy analysis of melon production using plasticulture. Acta Hort. 519:231-238.

Bianco, V.V. and H.K. Pratt. 1977. Compositional changes in muskmelons during development and in response to ethylene treatment. J. Amer. Soc. Hort. Sci. 102:127-133.

Blomgren, T. and T. Frisch. 2007. High tunnels: Using low cost technology to increase yields, improve quality, and extend the season. Univ. of Vermont Center for Sustainable Agr., Burlington, VT.

Bonanno, A.R. and W.J. Lamont. 1987. Effect of polyethylene mulches, irrigation method, and row covers on soil and air-temperature and yield of muskmelon. J. Amer. Soc. Hort. Sci. 112:735-738.

Bouwkamp, J.C., F.F. Angell, and F.D. Schales. 1978. Effects of weather on soluble solids of muskmelon. Sci. Hort. 8:265-271.

Carey, E.E., J. Lewis, W.J. Lamont, Jr., T.T. Nennich, M.D. Orzolek, and K.A. Williams. 2009. Horticultural crop production in high tunnels in the United States: A snapshot. HortTechnology 19:37-43.

Chace, E.M., C.G. Church, and F.E. Denny. 1924. Relation between the composition of California cantaloupes and their commercial maturity. Bul. U. S. Dept. Agr. 1250:1-26.

Hartz, T., M. Cantwell, J. Mickler, S. Mueller, S. Stoddard, and T. Turini. 2008. Cantaloupe production in California. UC ANR Publication 7218. Univ. of California, Oakland, CA.

Howell, J.C. and R.V. Hazzard (eds.). 2010. New England vegetable management guide. UMass Extension. Univ. of Massachusetts, Amherst, MA.

Jenni, S., D.C. Cloutier, G. Bourgeois, and K.A. Stewart. 1996. A heat unit model to predict growth and development of muskmelon to 
anthesis of perfect flowers. J. Amer. Soc. Hort. Sci. 121:274-280.

Jett, L. W. 2006a. High tunnel melon and watermelon production. Univ. Missouri Coop. Ext. Ser. Bul. M173.

Jett, L.W. 2006b. Galia muskmelons: A potentially profitable early-season crop for high tunnels in the Central Great Plains. 22 Nov. 2015. <http:// hightunnels.org/galia-muskmelons-a-potentiallyprofitable-early-season-crop-for-high-tunnels-inthe-central-great-plains/ $>$.

Kultur, F., H.C. Harrison, and J.E. Staub. 2001. Spacing and genotype effect fruit sugar concentration, yield, and fruit size of muskmelon. HortScience 36:274-278.

Lamb, E.M., N.L. Shaw, and D.J. Cantliffe. 2003. Galia muskmelons: Evaluation for Florida greenhouse production. Univ. Florida IFAS. Bul. HS919.

Lamont, Jr., W.J. 1996. What are the components of a plasticulture vegetable system? HortTechnology 6:150-154.

Lamont, Jr., W.J. 2009. Overview of the use of high tunnels worldwide. HortTechnology 19: 25-29.

Lingle, S.E. and J.R. Dunlap. 1987. Sucrose metabolism in netted muskmelon fruit during development. Plant Physiol. 84:386-389.
Loy, J.B. 2013. The nuts and bolts of fruit quality in cucurbits. Proceedings of the New England Vegetable and Fruit Conference 17-19 Dec., Manchester, NH. p. 201-204.

Loy, J.B. and O.S. Wells. 1975. Response of hybrid muskmelons to polyethylene row covers and black polyethylene mulch. Sci. Hort. 3:223-230.

Loy, J.B. and O.S. Wells. 1982. A comparison of slitted polyethylene and spunbonded polyester for plant row covers. HortScience 17:405-407.

MacGillivray, J.H. 1947. Soluble solids content of different regions of watermelons. Plant Physiol. 22:637-640.

Motsenbocker, C.E. and A.R. Bonanno. 1989. Row cover effects on air and soil temperatures and yield of muskmelon. HortScience 24:601-603.

Rodriguez, J.C., N.L. Shaw, and D.J. Cantliffe. 2007. Influence of plant density on yield and quality of greenhouse-grown Galia muskmelons. HortTechnology 17:580-585.

Sassenrath, G.F., J.M. Halloran, D. Archer, R.L. Raper, J. Hendrickson, P. Vadas, and J. Hanson. 2010. Drivers impacting the adoption of sustainable agricultural management systems of the northeast and southeast Unites States. J. Sust. Agr. 34:680-702.

Shaw, N.L., D.J. Cantliffe, J.C. Rodriquez, and C. Shine, III. 2004. Economic feasibility of producing
Galia muskmelons in passive ventilated greenhouses and soilless culture in north central Florida. Proc. Fla. State Hort. Soc. 117:38-42.

Tout, D. 1990. The horticulture industry of Almeria Province, Spain. Geogr. J. 156:304-312.

USDA, NASS. 2012. Census of Agriculture. United States Department of Agriculture. 22 Nov. 2015. $<$ http://www.agcensus.usda.gov/index.php $>$.

USDA, NASS. 2013. New England fruits and vegetables report, 2012 crop. 22 Nov. 2015. <http:// www.nass.usda.gov/Statistics_by_State/New_ England_includes/Publications/Special_Reports/ eosmar13.pdf>.

Waterer, D.R. 2003. Yields and economics of high tunnels for production of warm-season vegetable crops. HortTechnology 13:339-343.

Wells, O.S. and J.B. Loy. 1993. Rowcovers and high tunnels enhance crop production in the northeastern United States. HortTechnology 3:92-95.

Wells, J.A. and P.E. Nugent. 1980. Effect of high soil moisture on quality of muskmelon. HortScience 15:258-259.

Wiebe, J. 1973. Tunnel covers and mulches for muskmelon production. Can. J. Plant Sci. 53:157-160.

Woods, T.A. 2013. Vegetable and melon budgets. University of Kentucky College of Agriculture. 11 Nov. 2015. <http://www.uky.edu/Ag/CCD/ vegbudgets13.html $>$. 